\title{
CTC1 Gene Mutation
}

National Cancer Institute

\section{Source}

National Cancer Institute. CTC1 Gene Mutation. NCI Thesaurus. Code C152085.

A change in the nucleotide sequence of the CTC1 gene. 